FIU Law Review

Spring 2014

\title{
Creating a Seminole Enemy: Ethnic and Racial Diversity in the Conquest of Florida
}

Andrew K. Frank

Florida State University

Follow this and additional works at: https://ecollections.law.fiu.edu/lawreview

Part of the Other Law Commons

Online ISSN: 2643-7759

\section{Recommended Citation}

Andrew K. Frank, Creating a Seminole Enemy: Ethnic and Racial Diversity in the Conquest of Florida, 9 FIU L. Rev. 277 (2014).

DOI: https://dx.doi.org/10.25148/lawrev.9.2.9

This Article is brought to you for free and open access by eCollections. It has been accepted for inclusion in FIU Law Review by an authorized editor of eCollections. For more information, please contact lisdavis@fiu.edu. 


\title{
Creating a Seminole Enemy: Ethnic and Racial Diversity in the Conquest of Florida
}

\begin{abstract}
Andrew K. Frank*
The conquest of nineteenth-century Florida required more than signing and enforcing problematic treaties and waging violent expansionist wars on Native Americans. ${ }^{1}$ The United States fought multiple wars with Florida's Indians, with three of them explicitly designed to address the "Seminole problem," and it engineered and enforced several controversial removal treaties with them, most notably the treaties of Moultrie Creek (1823), Payne's Landing (1832), and Fort Gadsden (1833). ${ }^{2}$ As an important part of each of these actions, though, the United States also needed to employ a coherent yet fabricated definition of the enemy in order to justify their diplomatic and militaristic behavior. This essay demonstrates how nineteenth-century Americans defined the enemy in Florida as "Seminoles" and placed various unconnected or loosely connected groups under this umbrella term. Moreover, it shows how they widely and imprecisely used this euphemism in order to re-designate these communities as "runaways" and "criminals" rather than communities with sovereign rights to their lands. Some Native Americans-mostly Creeks from Georgia and Alabama who were engaged in their own process of nation-buildingjoined American policy makers as architects of this policy. ${ }^{3}$ This essay contextualizes the history of the Seminole wars while demonstrating the ways that an alliance of United States and Creek diplomats created and employed a self-serving definition of their enemies in Florida that justified the conquest of Native American people.

Nineteenth-century Americans created the idea of a "Seminole" nation,

* Allen Morris Associate Professor of History, Florida State University. Ph.D., University of Florida, 1998; M.A., University of Florida, 1994; B.A., Brandeis University, 1992.

1 Adam Wasserman, A PeOPle's History of Florida, 1513-1876: HoW Africans,

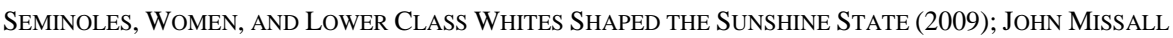
\& MARY LOU MisSALl, THE SEMINOLE WARS: AMERICA's LONGEST INDIAN CONFliCt (2004); JAMES G. CUSICK, THE OTHER WAR OF 1812: THE PATRIOT WAR AND THE AMERICAN INVASION OF SPANISH EAST Florida (2003); WiLliam S. BELKO, AMERICA's HundRED YEARS' WAR: U.S. EXPANSION tO THE GULF AND THE FATE OF THE SEMINOLE, 1763-1858 (2011).

2 ChARLES J. KAPPLER, INDIAN AFFAIRs: LAWS AND TREATIES 203-207, 344-55, 394-95 (1904).

3 This essay employs the term "nationalist" to describe the political outlook of a group that other scholars have termed "cosmopolitan" (to describe their cultural outlook) or "mestizo" (to emphasize a shared racial connection). See JAmes TAYlor Carson, SEARChing For the Bright PATH: THE MississipPi CHOCTAWS From Prehistory to Removal (1999); Claudio SAUNT, A NeW ORder of THINGS: PROPERTY, POWER, AND THE TRANSFORMATION OF THE CREEK INDIANS, 1733-1816 (1999).
\end{abstract}


even if Americans did not create the term itself. Spaniards, Englishmen, and perhaps some Native Americans used the term sparingly to describe a small community of Indians in the middle and end of eighteenth-century Florida. ${ }^{4}$ White Americans popularized the term "Seminole" in the nineteenth century, and then extended it to define all of the Native American (and sometimes African American) inhabitants in Florida. ${ }^{5}$ As they included more peoples in the imagined group, white Americans attached specific disparaging traits to it. Whereas many Seminoles in the early twentieth century poetically translated the Muskogee phrase (isti semoli) as "those who camp at a distance," "one who has camped out from the regular towns," or "free people at distant fires," representatives of the United States offered a different explanation in early America. ${ }^{6}$ With assistance from their Creek Indian allies and interpreters, who offered translations of their own, Americans insisted that the Muskogee phrase meant "runaways," "fugitives," and "wild people.," Modern scholars and even some modern Seminoles have followed suit, although many now accept the idea that the term originally derives from cimmarron, the Spanish term for runaway, rather than originating as isti semoli. ${ }^{8}$ Either way, the early American definition remains largely uncontested today. In addition, this definition of the term continues to be used to describe the Indians themselves. This occurs even though most indigenous peoples use names that reflect more about outside perceptions and misperceptions than about their origins as a people or their central characteristic. ${ }^{9}$ Indeed, part of the colonial process involved sorting, defining, and giving so-called "Indians" new names in order to understand and control them. ${ }^{10}$ In this way, the colonial process endures.

Not surprisingly, the Seminoles in the eighteenth and early nineteenth

4 SAUNT, supra note 3. BRENT R. WEISMAN, UNCONQUERED PEOPLE: FLORIDA's SEMINOLE AND MiCCOSUKEE INDIANS (1999).

5 DANiEl LitTlefield, AfricAns And SEMinOles: From REMOVAL TO EMANCIPATION 3-15 (1977).

6 JOHN REED SWANTON, INDIAN TRIBES OF NORTH AMERICA 139 (1952); MARJORY STONEMAN DOUGLAS, THE EVERGLADES: RIVER OF GRASS 185 (1947).

7 William C. STURTEVANT, Creek into Seminole, in NORTH AMERICAN INDIANS IN HISTORICAL PERSPECTIVE 92-128 (Eleanor Burke Leacock \& Nancy Oestreich, 1971).

8 George Stiggins, Creek Indian History: A Historical Narrative of the Genealogy Tradition, \& Downfall of the Ispocoga or Creek Tribe of Indians, Written by One of the Tribe (unpublished manuscript) (on file at Alabama Department of Archives and History, Montgomery); CALEB SwAN, Position and State of Manners and Arts in the Creek, or Muscogee Nation in 1791, in HISTORICAL AND StATISTICAL INFORMATION RESPECTING THE History, CONDITION AND PROSPECTS OF THE INDIAN TRIBES OF THE UnITED STATES, 1847 5:260 (Prepared by Henry R. Schoolcraft under the direction of the Bureau of Indian Affairs, 1852).

9 Joel Martin, SACred Revolt: The Muskogee Struggle for A NeW World 6-10 (1991).

10 RoBbie ETHRIDGE, CREEK COUNTRY: THE CREEK INDIANS AND THEIR WORLD 28 (2003). 
centuries did not consider themselves runaways, wild men, or fugitives from justice. They largely identified with their matrilineal clan families and their local villages (talwas), the most important political unit in the nonstate world that defined much of Native North America. ${ }^{11}$ When pressed, though, many of the so-called Seminoles considered themselves to be part of a loosely connected amalgam of Indians called Creeks. Cowkeeper, a renown leader of the Alachua village in the mid-eighteenth century, recognized that some Creek leaders used the term to describe him, but insisted, in 1774, that although he is "called a Wild man by the [Creek] Nation, it was not so."12 A decade earlier, a village leader in Florida declared his connection to the Creek people even though he was "considered by their Nation as Wild People."13 Indeed, throughout the eighteenth and nineteenth-centuries, as this essay demonstrates, the people called Seminoles rejected the term and the meanings associated with it. Over time, many (but not all) of the Florida Indians embraced the term, and rejected the derogatory meanings that the term implied.

The United States waged three wars against Florida's Indians in the first half of the nineteenth century. The wars have been widely remembered according to their numeric nomenclature: the First Seminole War (1816-1818), Second Seminole War (1835-1842), and Third Seminole War (1855-1858). ${ }^{14}$ In hindsight, these distinct wars formed a sustained campaign of conquest, with the United States intent on either removing or subjugating Florida's Native peoples, and otherwise pacifying the territory in order to secure its interests. ${ }^{15}$ From the beginning, these interests included creating a space for American slaveholders to expand their empire, limiting the ability of African American slaves to find freedom, and eliminating the Spanish and British presence in the region. ${ }^{16}$ These interests also overlapped with the desires of nationalist Creek Indians in Georgia and Alabama, who were led by chief William McIntosh, Jr. ${ }^{17}$ This ambitious and contentious leader sought to impose a centralized state onto his people

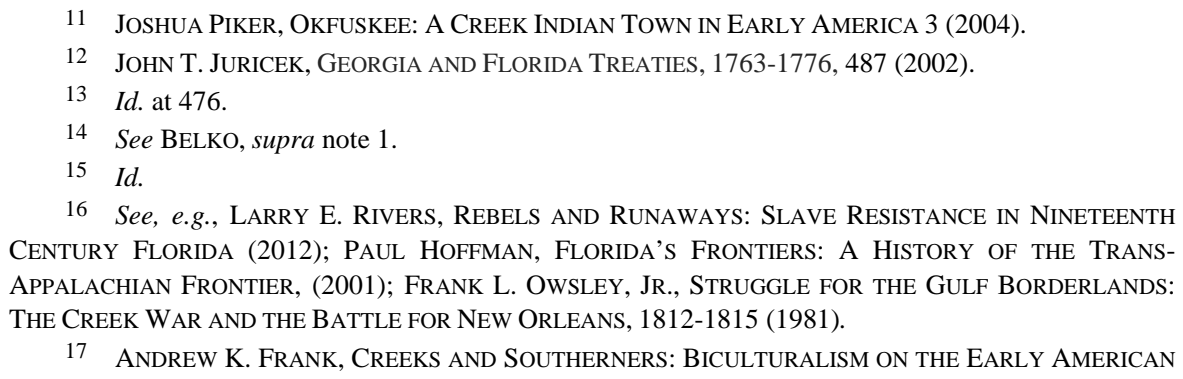

17 ANDREW K. FRANK, CREEKS AND SOUTHERNERS: BICULTURALISM ON THE EARLY AMERICAN FRONTIER 96-113 (2005). 
in order to secure a lasting peace with the United States and, not coincidentally, line his own pockets at the same time. ${ }^{18}$ Through the campaigns, the Indians in Florida resisted the threats of Creek and U.S. diplomats and soldiers, but by 1858 only a few hundred Indians remained in the state. Most Indians had either been killed or removed to the western Indian Territory. ${ }^{19}$ The Seminole Tribe of Florida and Miccosukee Tribe of Indians of Florida descend from the survivors who remained "unconquered" in Florida. Other descendants live as non-tribal members, or occasionally as members of the non-recognized Independent Traditional Seminole Nation of Florida (otherwise known as "Independents"). ${ }^{20}$

Attempts to conquer Florida began with the arrival of the Spanish in $1513 .^{21}$ Florida's Indian population of approximately 350,000 faced a fatal combination of European diseases, slave raids, and warfare, and in the sixteenth and seventeenth centuries the number of Indians in the territory plummeted. ${ }^{22}$ Catholic missionaries may have offered spiritual relief to the early generations of survivors, but they also aided the depopulation of Florida by creating densely settled congregations of Indians that were more prone to suffer from these very forces. ${ }^{23}$ Florida's indigenous population never disappeared, but by the eighteenth century, expansionist Americans could easily portray the land as being emptied of its original inhabitants and its current residents to be comprised solely of newcomers. ${ }^{24}$ Although it is likely that descendants of the Calusa, Apalachee, Timucua, Tequesta, and other ancient communities survived the onslaught and remained in Florida, the portrayals of a reoccupied Florida were at least partially correct. Hundreds, if not thousands, of Native American newcomers entered Florida throughout the colonial era and the migrations continued into the nineteenth century. ${ }^{25}$ Crossing Florida's northern boundary did not require migrants to cross a geographic or even political boundary for decades, and the FloridaGeorgia line remained contested into the nineteenth century. ${ }^{26}$ By the 1770s, Native American migrants had already established dozens of

\footnotetext{
18 Id. at 108-09; see also Michael D. Green, Politics of Indian Removal: Creek GOVERNMENT AND SOCIETY IN CRISIS (1985).

19 See generally MISSALL \& MISSALL, supra note 1.

20 HARry A. Kersey, JR., AN ASSUMption of SOVEREIGNTY: SOCIAL AND POlitical TRANSFORMATION AMONG THE FLORIDA SEMINOLES, 1953-1979 (1996); WEISMAN, supra note 4.

21 JERALD T. MILANICH, FLORIDA INDIANS AND THE INVASION FROM EUROPE (1998).

22 Id.

23 Id.

24 Jane Landers, Atlantic Creoles in the Age of ReVolutions 86 (2010).

25 Patrick Riordan, Finding Freedom in Florida: Native People, African Americans, and Colonists, 76 FlA. HIST. Q. 24, 24-43 (1996)

26 Martha C. Searcy, The Georgia-Florida Contest in the American Revolution, 1776-1778 (1985).
} 
villages in the Florida interior. ${ }^{27}$ African Americans made similar migrations, as they too fled from their New World bondage. ${ }^{28}$

The last significant wave of Native American migrants came to Florida in the early nineteenth century, and this wave directly aroused the desire of the United States to conquer and control Spanish Florida. ${ }^{29}$ In many ways, this conquest extended the dispossession of Indian lands in Georgia. There, local white settlers (first, under the English and later, the United States) orchestrated a series of land cessions from the various Indian communities in the eighteenth century. ${ }^{30}$ They took lands in exchange for the settling of questionable debts, as punishment for transgressions against diplomatic agreements, and under the guise of diplomacy but with the constant threat of war. $^{31}$ Indians disagreed over how to respond to these assaults, with some concluding that they needed to transform their political structure. ${ }^{32}$ This was especially true for the Cherokees, who resisted removal by creating a democratically elected national council who was authorized to engage the United States in formal diplomacy. ${ }^{33}$ Some Creek Indians, mirroring the Cherokee's path, similarly concluded that a formal national council would provide a greater negotiating position with the United States. $^{34}$ By the late eighteenth century, a small group of Creek Indians attempted to create (or at least create the appearance that they lived in) a centralized nation upon a largely decentralized network of villages that were located along the waterways of the southeastern interior. ${ }^{35}$

The imposition of a centralized government threatened many of the norms that characterized the Creeks and other southeastern Indian communities in the eighteenth century. The multiethnic and multilingual Creeks descended from ancestors whose Lower South communities "shattered" on account of the disease, warfare, and slave raids that accompanied European contact. ${ }^{36}$ Unlike in Florida, where the populations were nearly annihilated and the survivors largely disappeared, the survivors slightly to the north were just populous enough to regroup and form new

7 STURTEVANT, supra note 7, at 92-128.

28 JANE LANDERS, BLACK SOCIETY IN SPANISH FLORIDA 29-60 (1999); RIVERS, supra note 16.

29 ETHRIDGE, supra note 10, at 209.

30 DaVid W. Miller, The TAKing of Indian LANDS IN THE Southeast: A History OF TERRITORIAL CESSIONS AND FORCED RELOCATIONS, 1607-1840 at 20-27, 52-63 (2011).

31 Id. at 34

32 GREEN, supra note 18.

33 Theda Perdue, Cherokee Women: Gender And Culture Change, 1700-1835, 94 (1999).

34 FRANK, supra note 17, at 98-9.

35 Id. at 24; GREEN, supra note 18.

36 RobBie Ethridge AND SHERI M. SHUCK-HALl, MAPPING THE MisSisSipPian SHATTER Zone: The Colonial Indian Slave Trade AND REgional INSTABILITy in the AmERICAN SOUTH (2009). 
[Vol. 9:277

communities and polities. ${ }^{37}$ In the wake of massive depopulation and political destabilization, they formed a loosely-connected alliance of villages that kept their diverse ethnic and village identities intact. ${ }^{38}$ The Creeks were, as British naturalist Bernard Romans observed in 1775, "a mixture of the remains of the Cawittas, Talepoosas, Coosas, Apalchias, Conshacs or Coosades, Oakmulgis, Oconis, Okchoys, Alibamons, Natchez, Weetumkus, Pakanas, Taënsas, Chacsihoomas, Abékas and some other tribes whose names I do not recollect." ${ }^{39}$ Social and economic ties created loosely allied villages that would become known as Upper Creeks and Lower Creeks, but these connections were more proscriptive than prescriptive; more about the connections that could be perceived by outsiders than how the Indians actually behaved. As the coalescence of Creeks took place in Georgia, some Indian villages formed "irregular settlements" and a distinctive and social matrix in Florida that existed outside of the network formed by Georgia's waterways. ${ }^{40}$ As U.S. Indian agent Benjamin Hawkins explained about the Seminoles in 1799: "they are Creeks" from the towns of Oconee, Sawokli, Eufaula, Tamathli, Apalachicola, and Hitchiti. ${ }^{41}$

Despite the presence of a national council, early attempts by chief Alexander McGillivray and others to create multi-village or national alliances proved fleeting at best. Councils regularly met, but its authority remained subservient to the wishes of local village and clan leaders. ${ }^{42}$ In the early nineteenth century, a group of well-connected Creeks pursued centralization more effectively. ${ }^{43}$ Armed with powerful American allies, and the resources of the marketplace and a federal government whose "plan of civilization" provided various resources to transform Creek culture and politics, these leaders pursued a series of nationalist innovations. ${ }^{44}$ The nationalist Creeks worked with the centralized council to create a set of written laws, a standing police force, and various protections for private property. ${ }^{45}$ Most Creeks rejected or opposed these changes, and ultimately the process resulted in a civil war, widely known as the Red Stick War, which quickly became entangled in the War of $1812 .{ }^{46}$ Nationalist Creeks kept their alliance with the United States and the Red Stick majority found

37 Id.

38 FRANK, supra note 17, at 18-21.

39 BERNARD ROMANS, A CONCISE NATURAL HistORY OF EAST AND WEST FLORIDA 142 (1775)

40 C. L. GRANT, BENJAMIN HAWKINS: LETTERS, JOURNALS AND WRITINGS 243 (1980).

41 Id.

42 PIKER, supra note 11, at 116.

43 SAUNT, supra note 3.

44 Id.at 139-63.

45 Id. at 164-85.

46 Id. at 249-72. 
allies in Great Britain. The brutal war ended at the Battle of Horseshoe Bend, largely on account of the efforts of the United States military under General Andrew Jackson's command. Jackson would remain a longtime ally of Chief McIntosh. ${ }^{47}$ When the war ended, several thousand Red Stick Creeks escaped McIntosh's violent consolidation of power that followed the war by seeking refuge in Florida. ${ }^{48}$

In this context, the United States and the Creeks conspired together to construct a shared definition of the enemy that suited both of their purposes. This nineteenth-century definition of the Seminole changed over time and manifested itself differently as contexts demanded. Yet, at least three components of the definition deserve special attention. First, the Seminoles were made up of Indians, or Indian villages, who were runaways who had broken off from the Creek nation, and who became Seminoles when they crossed into Florida. Second, these runaways had allied themselves and mixed (diplomatically and racially) with African American runaways. Finally, the Seminoles constituted a monolithic Indian culture and community. They had legitimate political leaders who had authority to act on behalf of the entire nation. Not surprisingly, the resulting definition hardly matched the social reality that can be gathered from the historical record. Nor does the definition fit with many of the records created by those who aided in the conquest of Florida. Nevertheless, American policy makers and their Creek allies created, and then disseminated, this usable definition of Seminole that largely remains with us today.

Creek nationalists had much to gain by this definition-most particularly the idea that the Seminoles were runaways or fugitives of justice. This stance confirmed the legitimacy of the Creek national council and its laws, allowing the council and the nation it represented to appear as a legal reality rather than a contested fiction. Most Indians in Georgia and Florida did not believe that the Red Stick War resolved the debate over centralization and insisted that power and authority still belonged to their local village and clan leaders. ${ }^{49}$ Seminoles could only break off from something that was real—not something that was imposed, rejected, and illegitimate. The definition implies otherwise, and as the United States embraced this reality, it provided additional resources for the council to control recalcitrant Indian villages. The term also allowed the Creek council to extend its jurisdiction to the long-settled Indians in Florida, not

47 MARTIN, supra note 9, at 161-63; FRANK supra note 17, at 120-22.

48 SAUNT, supra note 3, at 249-72; CHARLES H. FAIRBANKS, ETHNOHISTORICAL REPORT ON THE FLORIDA SEMINOLES 211 (1974); JoHn R. SWANTON, THE INDIANS OF THE SOUTHEASTERN UNITED StAtes 181 (1946); StURTEVANT, supra note 7, at 92-128; J. LeITCH Wright, JR., CREeKS AND Seminoles: The Destruction and Regeneration of the Muscogulge People (1990).

49 SAUNT, supra note 3, at 273-75. 
just recently-arrived Red Sticks. Placing the Florida Indians under Creek control had potential financial and political benefits for the nationalist leaders, as they could obtain control over a greater share of the payments and other benefits that the removal treaties provided as compensation for eastern lands. By the end of the Second Seminole War, the Creek council concluded that it could not always control the Indians in Florida and it tinkered with the meaning of Seminole in order to deflect its responsibilities. ${ }^{50}$ The council increasingly relinquished its desire to control the Florida Indians and declared them to be "fugitives," "vagabonds" or "bandits." 51

The United States similarly benefited by uniting the diverse Florida Indians into the umbrella group of "Seminole" and connecting it to the Creek nation. For starters, embracing the euphemism simplified America's diplomatic situation. Rather than deal with dozens of local leaders and confront a cacophony of interests and voices, the term allowed the United States to rely on Creek nationalist chiefs who had already proven that they were willing to acquiesce to American demands. It also helped excuse a blatant land grab, as it erased any ancient claims of Indian sovereignty-i.e. the Seminoles were merely newcomers who were subject to laws elsewhere. United States diplomats expected and authorized the Creek national council to pacify the Florida Indians as a matter of its domestic policy. ${ }^{52}$ Moreover, the conflation of Creeks and Seminoles provided a pretense that justified all three Seminole wars. The Seminole wars began, American officials confidently and repeatedly asserted, when the Red Sticks initiated a revolt against the United States and the Creek council in 1813. "T3 "The war named the Seminole war," Americans widely presumed, "is a continuation of the Creek war." ${ }^{24}$ The U.S. invaded Spanish Florida in order to bring Creek (Seminole) fugitives to justice and necessarily had to remove these "hostile" Indians for the expansion into the Florida interior. ${ }^{55}$ Finally, the term "runaways" also allowed the United States to both simplify and blur the Indian connection with runaway slaves. Despite conflicting evidence, U.S. officials routinely declared that the Seminoles were partially of African descent-with generations of intermixing creating an unclear sense of who was Indian and who was slave. ${ }^{56}$

50 William Wragg Smith, SKetch of the Seminole War and SKetches During A CAMPAIGN 10 (D. J. Dowling 1836).

51 Id.

52 ETHRIDGE, supra note 10, at 232-38.

53 J. C. Calhoun et al., Seminole War, NiLES WKLY. REG., Mar. 20, 1819, at 178.

54 Id.

55 WRIGHT, supra note 48, at 202.

56 Kevin Mulroy, The Seminole Freedmen: A History 3-21 (2007); Rivers, supra note 16. 
The conflation of Creeks and Seminoles served diplomatic functions as early as the First Seminole War. The war partially began as a way for Jackson and McIntosh to consolidate their shared victory in the Red Stick War, and it required that they invade Spanish Florida and otherwise wage war where many surviving Red Sticks found shelter. ${ }^{57}$ Distinguishing recently arrived Red Sticks from second and third-generation individuals, however, was hardly easy or desirable. Many of the Red Stick refugees found homes among long-time residents, and American soldiers rarely had interest in differentiating between the two. The presence in Florida of free African Americans_-presumed by the United States to be runaway slavesfurther motivated the makers of war. ${ }^{58}$ White Southerners long harbored deep fears about the potential for slave and Indian rebellions, with the greatest fears aroused by their typically dormant yet potentially volatile alliance. Red Sticks and runaway slaves in Florida represented a united and unimaginable horror - what one U.S. Secretary of War portrayed as a "mingled horde of lawless Indians and negroes" who took "refuge within the Florida line." $" 59$ As in this description, white Americans repeatedly conflated the Indian and African communities despite knowing about the distinctions within and between them. ${ }^{60}$ When various agents for the United States military attempted to determine the size of the enemy in 1820s Florida, they carefully distinguished the number of recent Red Stick migrants, long-term Indian residents, and runway African American slaves. ${ }^{61}$ Yet, the wagers of the war typically employed very different language, emphasizing the presence of "negro chiefs," "negro Indians," and "Indian negroes." 62 Another method was to proclaim that a common British chief united the diverse enemies within Florida into a single army. ${ }^{63}$ When Jackson arrested two British agents-Robert C. Ambister and Alexander Arbuthnot-he accused them of providing assistance to the Red Stick or Seminole opposition, and in Jackson's words, were "acting as chiefs of the negroes and Indians" and thus "became identified with those monsters-

57 WRIGHT, supra note 48, at 202.

58 GARY Zellar, AFriCAN CREEKs: Estelveste AND THE CREEK NATION 20 (2007).

59 Congress of the United States, 311 American State PaPERs: Foreign Relations 540 (Nov. 28, 1818) (Asbury Dickins \& James C. Allen, eds., 1858).

60 KeVIN MulRoY, supra note 56, at 3-21.

61 Matthew T. Pearcy, Andre Atkinson Humphreys' Seminole War Field Journal, 85 FLA. HisT. Q. 197, 207-10 (2006).

62 H.R. Doc. No. 25-78, at 11, 60, 76, 91, 95, 110, 116, 447, 499, 607 (1838).

63 CONGRess of the United States, 1618 AMERICAN State PAPERS: Military AfFairs Defeat of the Seminole Indians 1:721-34, 757 (Apr. 26, 1818) (Walter Lowrie \& Matthew St. Clair Clark, eds., 1832). 
[Vol. 9:277

associated in the war!”64 This conflation of Seminole and African continued for generations, even outliving the wars themselves. ${ }^{65}$ As a result, modern understandings of nineteenth-century Florida frequently proclaim that "by this time ... so many blacks married into the tribe that it might have been impossible for an outsider to know for sure whether or not a person was of mixed race.”66

When the First Seminole War ended, American policymakers immediately recognized that Florida contained communities other than those defined by the presence of Red Stick Creeks and runaway slaves. ${ }^{67}$ In the 1823 Treaty of Moultrie Creek-the first treaty related to Florida after Spain ceded Florida to the United States in 1821-U.S. diplomats refrained from using the term "Seminole" at all. ${ }^{68}$ Instead, the treaty called upon various "chiefs and warriors, for themselves and their tribes," to accept the "protection" of the United States and relinquish their claims to most of northern Florida. ${ }^{69}$ The negotiations and the treaty itself acknowledged that the United States needed to deal with multiple "Florida tribes of Indians" rather than a singular centralized nation. ${ }^{70}$ U.S. negotiators dealt with various polities who all "speak their own tongue" (Muskogee, Hitchiti, and Yuchi) and who cherished their political and social distinctions from one another. ${ }^{71}$ The Indians of Florida included Creek migrants as well as some from "other tribes" who Horatio S. Dexter proclaimed "are very averse to be associated with other tribes in any assignments they may make with the U.S." ${ }^{2}$ These distinct Indian communities wanted their independence both from the United States and each other, and wanted to otherwise be left alone.

During the Seminole wars, many of the soldiers who fought the campaigns acknowledged that they were fighting more than one people as they invaded what they called Florida's "Seminole and Creek counties."73 Typical of commanders during the Second Seminole War, R. P. Parrot gave an accounting of the "Seminoles" in 1836 that acknowledged how much the

64 Id.

65 Thom Hatch, Osceola and the Great Seminole War: A StrugGle for Justice and FREEDOM 92 (2012).

66 Id.

67 KAPPLER, supra note 2, at 203-07.

68 Id.

$69 \quad$ Id. at 203.

70 Id.

71 Horatio S. Dexter, Observations of the Seminole Indians (1823) (unpublished manuscript) (on file with the Keenan-Brown Collection at the P.K. Yonge Library, University of Florida, Gainesville).

72 Id.

73 H.R. Doc. No. 25-78, at 3 (1837). 
term blurred out of the diverse reality. ${ }^{74}$ He stated, "[t]hose who came in yesterday represented the Uchee, Hitchitee, and Chehaw towns. They stated the Uchee warriors to be 200, and the Chehaw and Hitchitee to be 60 each; making 320 in all; and that these composed the great body of the hostile Indians."75 Colonel Jesup similarly distinguished "Tallahassers, ... Mickasukies, Uchees, and Seminoles” in his correspondence with Secretary of State Poinsett and others. ${ }^{76}$ Woodburn Potter repeated the idea that the term Seminole means "runaway" but insisted that "they are remnants of, and wanderers from, other tribes, principally of the Spanish Florida Indians, the upper Creeks of Muscogee, and the Miccosukee." "77 Policy makers, though, found it much easier to imagine a coherency to the "hostiles" and over time convinced those on the ground that they were all Seminoles or that "considerable portion" of Creeks and Seminoles were "practically one tribe."78 Nonetheless, even during removal, the great moment when the demographic data on many Indians were recorded, the United States agents charged with the job organized their work according to the distinctions among the Indians. Rather than counting the total number of Seminoles, they created separate counts for "Seminoles," "Tallehassees" "Mickasukies," "Creeks” and "Indian Negroes.,"79

Despite these observations, American diplomats found many ways to ignore rather than confront this reality. U.S. officials deployed rhetorical devices that united their enemies in Florida under the inflammatory "wild" Seminole character. ${ }^{80}$ In addition to emphasizing this definition of "Seminole," they drew upon the broader conceptions of unrestrained "hordes of savages" to conflate the enemy with what historian Peter Silver termed the "anti-Indian sublime." ${ }^{\text {" } 1}$ Typical of the American accounts, one explanation of the first war proclaimed that the Indian enemy "combated with the unrestrained fierceness of barbarians." 82 They had "the character

74 Id. at 579.

75 Id.

76 Id. at 171.

77 WoOdburne PotTer, The War in Florida: Being an Exposition of its CaUSes and ACCURATE History OF THE CAMPAignS OF GENERALS ClinCH, GAINES, AND SCOTT 8 (1836).

78 S. Doc. No. 59-5072, at 76 (1907).

79 Roll of the Indians at Tampa Bay (May 1, 1841) (unpublished manuscript) (on file with the Ah-Tah-Thi-Ki Museum, Seminole Tribe of Florida, Big Cypress Reservation).

80 H.R. Doc. No. 20-91, at 9 (1829); H.R. Doc. No. 24-271, at 81-83 (1835); SMITH, supra note 50 , at 41 .

81 See generally EUNICE BARBER, SHOCKING MURDER BY THE SAVAGES of Mr. DARIUS Barber's Family (1818); Peter Silver, Our SAVAge Neighbors: How Indian War TRANSFORMED EARLY AMERICA 84 (2007).

82 Occupation of Amelia Island, in THE LITERARY AND SCIENTIFIC REPOSITORY, AND CRITICAL REVIEW 161, 163 (1822). 
[Vol. 9:277

of wild beasts, fit only to be hunted down and exterminated."83 Another proclaimed that the Seminoles "saturated themselves with the blood of children and women." ${ }^{84}$ Andrew Jackson, for his part, proclaimed that the Seminoles "visited our frontier settlements with all the horrors of savage massacre; helpless women have been butchered, and the cradle stained with the blood of innocence.” ${ }^{, 5}$ By the 1840s, representatives of the United States routinely justified their conquest of the Indians because it would "relieve the citizens of Florida of a savage population, from which they have suffered, so much in rapine, conflagration, and murder." ${ }^{\text {"86 }}$ In doing so, they spread the myth that "they always attack dwellings at night" and "accomplish their deeds by of rapine and bloodshed." "7 The United States had no need to distinguish one enemy from another; they were at war with an enemy defined by and united in its savagery.

American officials further justified their aggressive policies by proclaiming that the Seminoles had violated Indian codes of conduct. ${ }^{88}$ As fugitives of Creek laws, the Seminoles deserved the subjugation and harsh treatment of conquest. In 1826, James Gadsden-a Territorial representative who repeatedly received authorization by the federal government to negotiate the removal of the Indians of Florida-typified the American strategy. " "The Territory of Florida Indians," he declared, "is not involved in the mists of antiquity [nor] need we examine old treaties or Spanish policy to ascertain their rights or claims. The aborigines of the Country have long since been extirpated." 90 The Seminoles, he explained, lacked legitimate claims to sovereignty. Instead, the "Indians occupied the most desirable part of Florida ... claiming it [through] conquest."91 Not surprisingly, Gadsden concluded, "they were only to be treated with the same principles." ${ }^{2}$ Gadsden's justification for war paralleled another method of artificially uniting the Seminoles together and relied on merging the widely known history of Red Stick migrants with the translation that

83 Id. at 163.

84 MichaEl D. ROGin, FATHERS AND CHILDREN: ANDREW JACKSON AND THE SUBJUGATION OF THE AMERICAN INDIAN 123 (1991).

85 CHRISTINA SNyder, SLAVERY In INDIAN COUNTRY: THE CHANGING FACE OF CAPTIVITY IN EARLY AMERICA 219 (2010).

86 T. HARTLEy CRAWFord, ANNUAL REPORT OF THE COMMISSIONERS OF INDIAN AFFAiRs 20 (1840).

87 Latest News from Florida, ARMY \& NAVY CHRON., (Feb. 20, 1840).

88 James Gadsden to James Barbour, THE TERRITORIAL PAPERS OF THE UNITED STATES, Vol. XXIV, The Territory of Florida, 1828-1834, at 489-93 (Mar. 26, 1826) (Clarence Edwin Carter, ed. 1958).

89 Id.

$90 \quad$ Id.

91 See id.

92 Id. 
equated "Seminoles" with "runaways." U.S. Indian Agent Wiley Thompson made the sleight of hand remarkably clear: "The word Seminole means runaway or broken off," he explained. ${ }^{93}$ Therefore, "it is applicable to all the Indians in the Territory of Florida as all of them ran away ... from the Creek... Nation."94 For this reason, "the Treaties made with the Seminole Indians embrace all of the Indians in the Territory except for some bands on the Apalachicola River who were provided for in a separate Article in the Treaty of Moultrie Creek." 95 This myth-that the Seminoles had violated Creek laws and escaped punishment by running to Floridaendured. $^{96}$ In 1851, Indian agents continued to complain about the Seminoles because "their unwillingness to submit to Creek laws or Creek authority still continues." 97 Indeed, "it was this indisposition to submit to Creek laws... which induced them to leave the 'country of their fathers." "98

Throughout the nineteenth century, the Florida Indians protested that the United States frequently ignored their ancient roots and internal divisions. Their protests became especially pronounced when the United States asked Native American leaders to make decisions for communities over whom they had no authority. ${ }^{99}$ Outrage also occurred when American officials diminished the Indian claims to their lands. ${ }^{100}$ Micanopy, for example, insisted that he was not a recent arrival to Florida and thus had sovereign rights to his lands. ${ }^{101}$ "Here our navel strings were first cut and blood from them sunk into the earth, and made the country dear to us," he explained. ${ }^{102}$ Even though Micanopy was widely recognized as one of the most influential Indian leaders during the Second Seminole War, U.S. officials widely ignored his claims that he had ties to ancient Florida. ${ }^{103}$ Chief Halleck similarly protested that his people had "broken off" from the Creeks. ${ }^{104}$ "I had always lived here, and when a boy travelled over the country with my bow and arrow: here my father was buried, and I thought I

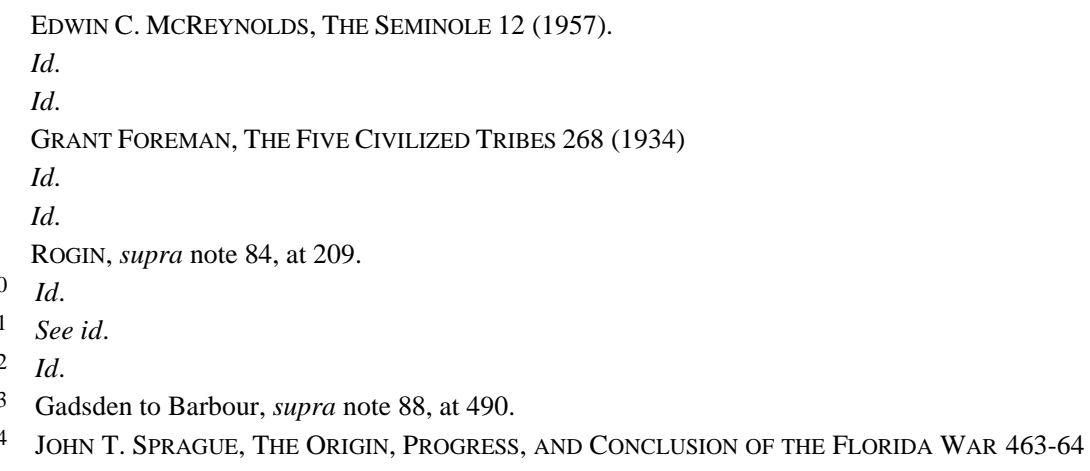


might as well die here as to go to another country and die.”105 These protests outlived the era of the wars, with Native Americans insisting that their communities included ancient Floridians. ${ }^{106}$

Treating the Seminoles as if they were part of the Creek nation who left it illegally, though, remained an important part of American diplomatic policy. In 1829, a Georgia Commissioner made this connection explicit in his demands for the Creek government to control them: "[w]e consider those people, the Seminoles, a part of the Creek nation, and we look for the chiefs of the Creek nation to cause the people there ... to do justice."107 A few years later, in the 1832 Treaty of Payne's Landing, the United States sought to convince the Florida Indians "to reunite ... as one people" with the Creeks in Indian Territory. ${ }^{108}$ Agents for the United States pushed the policy because it simplified the process even though they were aware of widespread opposition in Florida's Indian communities. ${ }^{109}$ They noticed that they spoke "practically [but not exactly] the same language," and they frequently concluded that being forced to join the Creeks was the "essential cause of their reluctance to go off." 110 As they sought to enforce this treaty, Thompson and the United States used the translation of Seminole as "runaway or broken off" as a justification to expect all Indians in Florida to adhere to terms of the treaty and the policy of removal. ${ }^{111}$ They expected compliance by all Native Americans, even so-called "Spanish Indians” who lived along the gulf and not on the reservation lands that were explicitly mentioned in the treaty. ${ }^{112}$

Imagining a single Seminole enemy happened rather effortlessly because American policy makers commonly assumed that Indians lived in nation-states comparable to their own. When white Americans were colonists, they often turned chiefs into kings; in the early republic, they commonly turned chiefs into representatives. ${ }^{113}$ When Seminole leaders met in ad hoc councils, the United States presumed that it was a standing organization and something that U.S. officials could attempt to try to control in order to achieve its ambitions. ${ }^{114}$ The decision of the United

105 Id.

106 In 1896, a Florida Seminole, named Wild Cat, declared that the Seminoles "descended from giants, 6 or 8 feet tall who 'had always lived here.”” FRANCES DENSMORE, SEMINOLE MusiC 5 (1956).

107 WASSERMAN, supra note 1 , at 194.

108 KAPPLER, supra note 2, at 344-55.

109 Id.

110 Indian War, CHRISTIAN REGISTER \& BOSTON OBSERVER, July 9, 1836.

111 MCREYNOLDS, supra note 93, at 12.

112 Id.

113 DANIEL RiChter, FACING EAST FROM INDIAN COUNTRY: A NATIVE History OF EARLY AMERICA 167 (2001).

114 Richard A. Sattler, Remnants, Renegades, and Runaways: Seminole Ethnogenesis 
States to treat the Seminoles as a single polity did more than insult the Seminole's sense of history; it also shaped the internal diplomacy of the tribe. $^{115}$ By lumping peoples of various allegiances and backgrounds together, the United States effectively created the myth that there were legitimate national leaders who could make decisions (however disagreeable) for the whole of the Seminole people. ${ }^{116}$ This allowed the United States either to conquer the Indians or find a few chiefs who were "best affected to the United States" to sign away lands that they did not actually control. ${ }^{117}$ The United States found willing accomplices (often through coercion or fraud) during each treaty negotiation, and then used their false idea about Seminole government to enforce them. ${ }^{118}$ Rather than seeing legitimate grievances that localism allows, Americans frequently marginalized dissent by imagining that the Seminole nation had a formal structure with political parties. Florida Senator James Westcott, for example, determined that Micanopy "was king of the nation, and is opposed to going." "John Hicks, the war chief, heads the other party. Jumper, the orator, or the sense keeper, is on both sides. ${ }^{120}$ Other Americans imposed ideas of hereditary rule to several leaders including Jumper — even though "he denies it, and objects to being so called."

After the Treaty of Payne's Landing (and the subsequent 1833 Treaty of Fort Gadsden where a handful of Indian signees declared that the western lands were suitable for resettling), American policy makers pursued the problematic issue of reunification with the Creeks. ${ }^{122}$ In 1838, Senator Thomas Hart Benton explained that the Seminoles were an "emigrant band of the Creeks" and therefore should be reunited in the west. ${ }^{123}$ There, he explained in words taken directly from the Treaty of Payne's Landing, the "Seminoles would be received as a constituent part of the Creek nation and will be readmitted to all the privileges as a member of the nation."124 Various other wartime sources continued to confirm that this was an

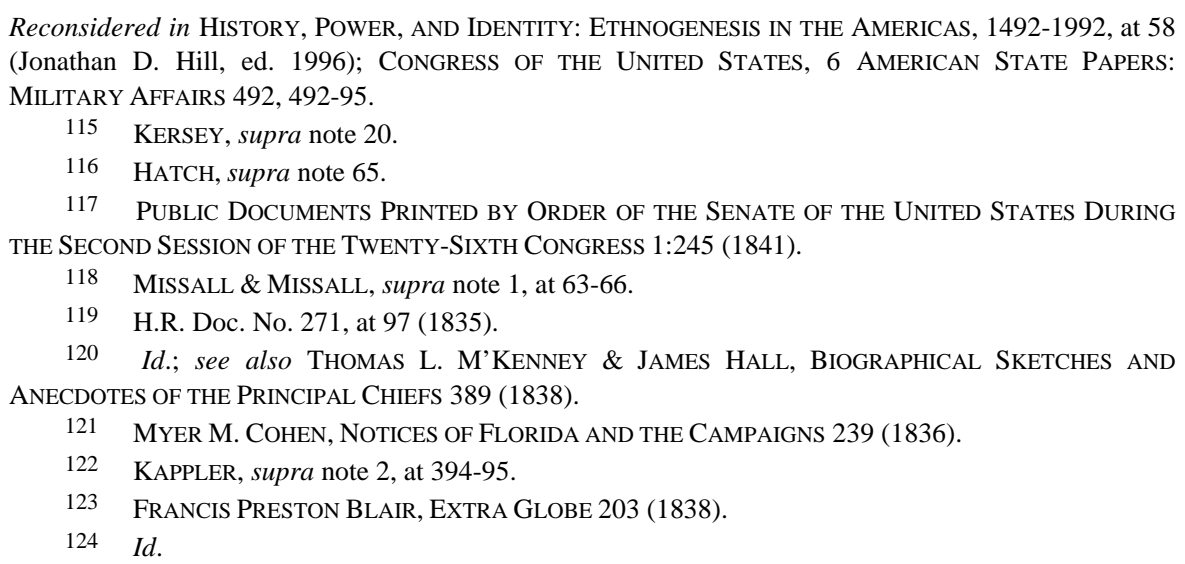


appropriate course of action. ${ }^{125}$ The Army and Navy Chronicle, for example, reprinted many stories that reminded its readers that the Seminoles had no real connections to Florida. ${ }^{126}$ "Of the former inhabitants of Florida they know nothing," one article explained. "Nor do they know more of themselves than that they are a remnant of the tribe of Muscogees (or Creeks), which formerly inhabited Georgia and Alabama."127 Indian protests eventually broke through, as some American policy makers reluctantly recognized that resistance to removal occasionally weakened when Seminole were promised their own lands rather that being asked to become part of the Creek.

The era of the Seminole Wars resulted in the death or removal of all but a few hundred Indians from Florida. ${ }^{128}$ As part of this process of conquest, the United States created and imposed a definition of the Seminoles that was widely rejected by the Native Americans themselves. The definition declared that the Seminoles were wild savages who escaped Creek laws, intermixed with African Americans, and ultimately formed an illegitimate nation of their own. The definition defied reality, but allowed the United States to treat the Florida Indians as if they belonged with or remained connected to various other Indian communities. Sometimes this meant acting on connections, real and imagined, between the diverse groups of Floridians who became lumped together as Seminoles (whether they were Apalachee, Muskogee, Miccosukee, or Spanish Indians). It also led the United States to treat the Florida Indians as if they were connected with the Creeks in Georgia or in the western Indian Territory.

Since then, far too many outsiders continue to replicate the definition of Seminoles that the United States created for the purposes of conquest and then recorded in a problematic historical record. As much as Native Floridians make claims to the contrary, the Seminoles remain former Creeks who seceded, moved to Florida, and intermixed with African American runaways. ${ }^{129}$ Yet the Indian voices of dissent remain clear. Many early twentieth-century anthropologists discovered that "[t]he

125 Florida, ARMY AND NAVy Chron., Aug. 8, 1839.

126 Id.

127 Id

128 MisSALL \& MisSALL, supra note 1, at 221-22.

129 StURTEVANT, supra note 7, at 92-128; Sattler, supra note 114, at 37; BRENT RICHARDS Weisman, LiKe BEAdS ON A StRing: A Culture History of the SEMINOLE INDIANS IN NORTHERN PENINSUlar Florida 38 (1989); HofFMAN, supra note 16, at 215; SUSAN A. Miller, COACOOCHEE’S Bones: A Seminole SAga 7-9 (2003); Charles Fairbanks, Ethnohistorical REPORT ON the FLORIDA INDIANS 132 (1974). 
Seminole of Southern Florida, known as the Cypress Swamp group, resent the idea of relationship with Creek tribe, saying this is limited to the northern ... Cow Creek group."130 Perhaps most obviously, in the late 1950s and early 1960s, Miccosukee-speakers who lived quite a distance from other Indian communities near Lake Okeechobee struggled to convince the United States that they represented a distinct community with a distinct history and culture. ${ }^{131}$ They ultimately established the Miccosukee Tribe of Florida Indians and became a separate polity than the Seminole Tribe of Florida in 1962. ${ }^{132}$ Even Seminole leaders, many of whom opposed the separation of the Miccosukee for political and economic reasons, embraced the diversity within their community. ${ }^{133}$ Former Seminole chairman Betty Mae Tiger Jumper, for example, proclaimed " $[t]$ he Florida Indians are direct descendants of the last remnants of the legendary Seminole Nation-a combination of Creek and other tribes chased from indigenous southeastern homelands into Florida during the early [nineteenth] century."134 More radical Indian voices have insisted on their connection to ancient Florida and therefore deserve status as being indigenous rather than newcomers. ${ }^{135}$ Medicine man and activist Bobby Billie emphatically contends that academics and outsiders, "have written, in their books, that the Simanolee People come from the 'Creek.",136 The Simanolee People did not come from the Creek. They came from the Earth, and the Law we follow comes from the Creator (God) Himself at the beginning of the Creation of Life. ${ }^{137}$ This debate over the history of Florida's Indians and the nature of the Seminole wars promises to endure into the future. As it continues, one can hope that scholars recognize the intentional and self-serving bias of the historic record and allow Native American perspectives to be illuminated.

130 DENSMORE, supra note 106, at 6.

131 Buffalo Tiger \& Harry A. Kersey, JR., Buffalo Tiger: A Life in the Everglades 138-42 (2008).

132 KERSEY, supra note 20, at 182.

133 Betty MAE Jumper, LEgends of the SEMinOle 13 (1994).

134 Id. (emphasis added).

135 Bobby C. Billie, Council of the Origins Miccosukee Simanolee Nation Aboriginal People Statement (December 6, 2011) (on file with author).

136 Id.

137 Id. An important work that ties the Muskogee peoples to the ancient southeast is PATRICIA Riles Wickman, The Tree That Bends: Discourse, Power, and the Survival of the MaskoKi PEOPLE (1999). 